\title{
Material Encounters and Indigenous Transformations in the Early Colonial Americas
}

\author{
Floris W.M. Keehnen, Corinne L. Hofman, and Andrzej T. Antczak
}

Contributions of indigenous peoples to colonial encounters in the Americas were profound, varied, and dynamic. Instead of mere respondents, let alone passive bystanders, indigenous peoples were active agents in processes of colonialism, vital in the negotiation and recreation of new colonial realities. Paradoxically, they have long been some of the most invisible craftsmen of today's societies. However, recent archaeological scholarship continues to provide material evidence that suggests that notwithstanding the severe and enduring impacts of intruding colonial powers, indigenous peoples continued to make choices that would benefit them. Among the many strategies they chose were alliance making, intermarriage, cooperation, negotiation, trading, escape, resistance, rebellion, and armed conflict. Engagement in this range of (flexible) friendly and antagonistic social and material relationships was not restricted to two-sided indigenous-European affairs. Quite the contrary, colonial processes resulted as much in shifting relations and identities among indigenous peoples, Africans, and Europeans themselves, as well as between indigenous peoples and Africans, and Europeans and Africans.

Over the past few decades, the study of colonial contact and interaction has progressed significantly with the adoption of new and revised theoretical paradigms, innovative research approaches, and multiscalar perspectives. Since the late 1990s, a conceptual framework has come to fruition that highlights colonialism's entangled and transformative nature on the premise that all parties contributed to and were impacted by the process of interactions through negotiation, creativity, and innovation. Focusing on these and related aspects including local agency, power, and resistance, as well as social constructs such as gender, race, class, and identity, archaeologists have advanced considerably in reconstructing indigenous lives in colonial settings (e.g., Anderson-Córdova

1 This introductory chapter is largely based on the introduction chapter of the $\mathrm{PhD}$ dissertation Values and Valuables by Floris Keehnen (forthcoming). 
2017; Cipolla and Hayes 2015; Deagan 2003, 2004; Dietler 2010; Ferris 2009; Ferris et al. 2014; Funari and Senatore 2015; Given 2004; Graham 2011; Liebmann and Murphy 2011; Loren 2008, 2010; Murray 2004; Oland et al. 2012; RodríguezAlegría 2016; Rothschild 2003, 2006; Rubertone 2000; Scheiber and Mitchell 2010; Silliman 2005, 2009; Stein 2005; Torrence and Clarke 2000; Valcárcel Rojas 2012, 2016; Van Buren 2010; Voss and Casella 2012; Whitehead 2011).

Despite addressing these important nuances, European colonialism was an unmistakably painful process, the effects of which - many still felt today cannot and should not be minimized. Many groups were severely restricted in their self-determination, some of whom never were able to stand up to their oppressor or make choices for themselves. The current trend of decolonizing indigenous histories aims to investigate this interplay of individual experiences amidst (hostile) colonial realities (see also Atalay 2006; Bruchac et al. 2010; Jansen and Raffa 2015; McNiven 2016; Silliman 2012; Smith and Wobst 2005). To date, efforts to disrupt the many and long persistent "Grand Narratives" of European colonialism (Voss 2015) and to decolonize archaeology by recognizing long-term indigenous trajectories in fine-grained views of history (Oland et al. 2012) continue to be successful.

The developments outlined above have also promoted the understanding of the roles of material culture in processes of colonialism (e.g., Card 2013; Cipolla 2017; Cobb 2003; Cusick 1998; Funari and Senatore 2015; Gosden 2004; Liebmann 2015; Lightfoot et al. 1998; Lyons and Papadopoulos 2002; Maran and Stockhammer 2012; Richard 2015; Rodríguez-Alegría 2008, 2010; Rogers 1990; Rothschild 2003, 2006; Scaramelli and Tarble de Scaramelli 2005; Silliman 2010, 2016; Thomas 1991; Van Dommelen 2006). With respect to the study of colonial encounters in the Americas, an interest was raised in exploring the indigenous appropriation of European material culture through gifts, trade, or imitation. It resulted in the rethinking of ideas about the indigenous adoption or resistance of foreign objects, and how such differential choices not only altered indigenous material assemblages, but also affected existing social, political, and economic structures. Nowadays, our understanding of material encounters in the colonial Americas largely comes from case studies in North America, where over the past decades updated theories on, for example, consumption, hybridity, and entanglement, have already been successfully applied. Building upon these efforts, this volume will specifically target the previously underrepresented Caribbean and its surrounding mainland(s), thereby focusing on the period of Spanish/European colonialism from AD 1492 to 1800 . Working from a critical understanding of indigenous long-term historical trajectories, the authors will discuss how foreign goods were differentially employed across time, space, and scale; how these were considered within indigenous ontologies 
and value systems; what implications their adoption had for larger indigenous society; and which theoretical approaches and methodologies better help us understand indigenous material practices.

\section{Towards a Material Perspective of Colonial Encounters} in the Americas

In the Americas, including the broader Caribbean region defined above, the efforts of many scholars have greatly contributed to the creation of a more balanced and better-informed understanding of early colonial dynamics. Yet, whereas social and cultural issues of the colonial period have been important topics of inquiry, only a few studies on indigenous histories in this part of the Americas have taken a more profound interest into material aspects of the colonial encounter (e.g., Boomert 2002; Cooper et al. 2008; Crosby 1972; Deagan 2004; Ernst and Hofman 2015; Funari and Senatore 2015; Graham 2011; Hofman et al. 2014; Ibarra Rojas 2003; Keehnen 2011, 2012; Mol 2008; Morsink 2015; Oland 2014; Oliver 2009; Ortiz 1995; Ostapkowicz 2013; Pugh 2009; Rodríguez-Alegría 2008, 2010; Scaramelli and Tarble de Scaramelli 2005; Valcárcel Rojas 2012, 2016; Valcárcel Rojas et al. 2010, 2013; Vega 1979, 1987). In fact, the central importance of (foreign) objects has never been fully examined for early colonial settings in this region. Of course, transformations of indigenous material culture repertoires resulting from European contact have been discussed earlier. However, these realizations often followed occasional findings of European materials in indigenous assemblages or the labeling of recovered ceramics as "transcultural." An integrated, synthetic approach on the topic, however, has been lacking so far; a missing part of a much larger issue, which involves the extremely limited work done on the archaeology of the Spanish/European colonial period. Although new insights over the last few decades have promoted the study of transculturation and indigenous and African responses to colonialism, the field seems to have remained an offshoot of pre-Columbian research with a predisposition towards European perspectives (Deagan 2004; Ewen 2001). As a result, indigenous experiences amidst new colonial realities are still poorly understood and merit further investigation if we aim to reach a more inclusive understanding of this turbulent period in the history of the region (Valcárcel Rojas 2012, 2016).

Recently, numerous studies of colonialism worldwide have shown that the exchange and adoption ("consumption") of material elements of the 'other' were vital for the establishment and structuring of interethnic relationships (e.g., Cusick 1998; Van Dommelen 2006; Gosden 2004; Lightfoot et al. 1998; 
Lyons and Papadopoulos 2002; Maran and Stockhammer 2012; Rogers 1990; Rubertone 2000; Silliman 2010; Thomas 1991). In addition, objects embodied and directed transformations in social, cultural, and material domains for all of those involved. Especially in the Caribbean - the nexus of first interactions between groups from Europe, Africa, and the Americas - it is most interesting to unravel the entanglement of widely divergent material culture repertoires (Hofman 2019; Hofman et al. 2012; Keehnen and Mol 2018). Here, with no previous contact, indigenous communities and Spanish/European explorers and colonists used objects to negotiate a mutual base of understanding. Studying the material components of colonial encounters provides insights into respective value systems and reveals the various social mechanisms that were at play. Furthermore, it is through the analysis of practices including gift giving or the voluntary adoption of previously unknown types of objects, that it is possible to retrace aspects of indigenous agency - particularly important here or in similar situations in which these tend to become obscured.

From reading late fifteenth- and early sixteenth-century (ethno)historical sources on the first encounters in the Caribbean islands, the basic material constituents of these interactions are known: on the one hand, a European assembly of "trinkets" (beads, bells, and other shiny items) previously already used to successfully entice native peoples living in West Africa and the Canary Islands (cf. Fernández-Armesto 1987; Graeber 1996); and, on the other hand, indigenous Caribbean gold, pearls, and foodstuffs, and especially valued lustrous objects (Hofman et al. 2018; Keehnen 2011, 2012; Oliver 2000; Saunders 1999). ${ }^{2}$ However, we know very little about the materiality of these things, their interconnections, and the underlying social and cognate mechanisms facilitating the flow of objects within and between the different cultural groups involved in the encounters. With the present volume, it is our aim that this contribution fills part of this lacuna by focusing on the materiality of things in early colonial encounters in the Caribbean and adjacent mainland areas. We specifically focus on the nature of indigenous and Spanish/European object realms, the types of objects that enabled both parties to connect upon contact, and the underlying systems of value allowing for the adoption of new types of material culture. We want to explore how objects transcended cultural boundaries, how 'cultural others' dealt with such articles after their 'foreign' adoption, and what changes we can observe in the material interrelations, practices, and valuations of indigenous

2 What is more, in due time Europeans started to import indigenous material culture from other parts of the circum-Caribbean area into the islands to use in their interactions with the island inhabitants (Valcárcel Rojas 2012, 2016). 
societies. Finally, we evaluate how these material dynamics contribute to our broader understanding of early colonial encounters in the first regions of the Americas that were impacted by the European colonization.

\section{3}

A Matter of Concept(s)

Early colonial patterns and connections have not always been appreciated for their entangled and transformative character. To provide a contextual framing of previous studies and ideas, we will discuss a selection of the most important past scholarly advances in the field and their influence on the development of Spanish/European colonial archaeology in the broader Caribbean region, including the adjacent parts of the continental coasts (for summaries, see also Deagan 1998; Hernández Mora 2011; Valcárcel Rojas et al. 2013; Van Buren 2010).

The theme of culture contact and change has been ingrained in the disciplines of anthropology and archaeology since their very beginnings, particularly in the Americas, given the profound impact of post-1500 European colonialism in the region. Starting in the 1930s, and firmly established in the 1950 s and 196os, interactions between European and non-European peoples were generally explained in terms of the "acculturation" model (Beals 1953; Herskovits 1938; Kroeber 1948, 425-437; Redfield et al. 1936). The theory's key premise was that the dominant colonizing "donor" culture transforms the more passive "recipient" culture, resulting in the loss and eventual disappearance of traditional lifeways, materialities, and even entire cultures. Analyses of contact situations thus focused on determining the degree of change indigenous "subordinate" cultures had undergone because of Western contact. These changes (classified into types or stages) were considered unidirectional, given the idea that power resided exclusively with the "culture bearing" (and, by extension, "civilization bearing") Europeans (but see Foster 196o; Spicer 1961). In an influential study, George Quimby and Alexander Spoehr (1951) proposed a methodology to assess the rate of indigenous acculturation in colonial artifact assemblages. Their classification scheme distinguished between (modified) traditional, introduced, and mixed objects based on artifact form, material, use, and manufacture. The model long remained popular and has been adopted and amplified by archaeologists in different ways (for relatively recent examples, see Farnsworth 1989, 1992; cf. Rogers 1990, 1993). In this context, European technologies and materials were generally regarded as superior (i.e., more efficient and sophisticated) to indigenous ones, leading to ideas about the inevitability of cultural and technological progress to promote a 
theory of immediate replacement (e.g., Elliott 2002; Foster 1960; Pasztory 2005; Trigger 1991).

For the ensuing decades, the acculturation concept remained the dominant model for studies of culture contact. Ironically, it was the search for the origins of modern capitalism during the 1970s - the basis of Wallerstein's world-systems theory $(1974,1980)$ - that resulted in an increased scholarly awareness of the position of indigenous communities. In the establishment of the colonial network, these indigenous - or "pre-state" - societies were the "peripheries" of the nation-state "cores," distant nodes of exploitation vital for the emergence of Europe's global mercantilist and imperialist structures. Within the world system, both entities were crucial for the larger interlinked and interdependent whole. As a result of their intimate connection, changes on either side were understood to directly affect the other, although it was the nation-state dictating this relation, a structured inequality that eventually hindered further development of the colonies (see, e.g., Frank 1966). For one thing, it was realized that a core-periphery entanglement was required to study both parts in tandem, thereby stretching the unit of analysis to encompass both (cf. Braudel 1981).

A turning point in the anthropological perception of indigenous peoples contacted by Europeans was reached with the publication of Eric Wolf's (1982) influential work Europe and the People Without History, which for the first time advocated a "bottom-up" understanding of colonial situations. Although world-systems theory proponents had urged scholars to include peripheral colonies, the approach contributed little to understand the active participation of these areas in the creation of the larger commercial system, nor as (precontact) entities on their own, with local historically defined dynamics and particularities. To restore this imbalance, anthropologists were to take up responsibility for the study of indigenous historical trajectories, even to look for similar phenomena among past societies on a worldwide scale (e.g., AbuLughod 1989; Algaze 1993; Blanton and Feinman 1984; Schneider 1977; for a review, see Hall and Chase-Dunn 1993). Moreover, many influential publications sprouted from the burgeoning interest in issues of European colonialism and indigenous responses (Fitzhugh 1985; Ramenofsky 1987; Rogers 1990; Rogers and Wilson 1993; Thomas, ed., 1989, 1990, 1991; Wylie 1992).

Meanwhile, as post-processual and postcolonial theories became more widespread, both the acculturation model and the world-systems theory were discarded for being passive, unidirectional, and ethnocentric (see essays in Cusick 1998). The emphasis on concepts such as agency, practice, and identity, building upon the foundational works of Sahlins (1976), Bourdieu (1977), and Giddens (1979), as well as the reconsideration of Western cultural 
representations of "the other," represented by Edward Said's Orientalism (1978), called upon a more inclusive and multidimensional approach to colonial interaction in pluralistic social settings (Lightfoot et al. 1998). These theoretical advances resulted in the formulation of a range of new and updated concepts about cultural mixture, including bricolage (Comaroff 1985), creolization (Dawdy 2000; Deagan 1996; Deetz 1996; Delle 2000; Ewen 2000; Ferguson 1992; Hannerz 1987; Mintz and Price 1992), ethnogenesis (Deagan 1998; Hill 1996; Moore 1994), hybridity (Bhabha 1994; Hall 1990; Silliman 2015; Young 1995), mestizaje (Deagan 1974, 1983), syncretism (Palmié 1995; Stewart and Shaw 1994), and transculturation (Deagan 1998; Domínguez 1978; Ortiz 1995; Romero 1981). But, as part of this ongoing reconfiguration of historical anthropology, it was realized that to understand cultural continuities and changes following European contact, it is critical to perceive of these as grounded in a precolonial past. Hence, the categorical separation between a "prehistoric" or "precontact" period and a "historical" or "postcontact" period became heavily criticized for being an artificial and Eurocentric construct (e.g., Lightfoot 1995; Rubertone 1996, 2000; Schneiber and Mitchell 2010; Williamson 2004). Such a "historical divide" frames European contact as a defining moment in the lives of indigenous peoples, overlooking indigenous long-term histories as well as their presence and performances in early colonial times and up until the present (Boomert 2016; Hofman et al. 2012; Oland et al. 2012, 1).

In anticipation of the Columbian Quincentenary in 1992 (the 500-year "anniversary" of Columbus' fortuitous arrival in the Caribbean), scholars all over the Americas increasingly embraced the topic of European colonization and "first contact" situations (e.g., Bray 1993; Deagan 1985, 1987, 1988; Fitzhugh 1985; Greenblatt 1991, 1993; Hulme 1986; Pagden 1993; Ramenofsky 1987; Rogers 1990; Rogers and Wilson 1993; Wilson 1990; Wylie 1992; see also Axtell 1995). In the insular Caribbean, it was only then that archaeological research of the "contact period" started to boom. ${ }^{3}$ Before this time, Spanish colonial archaeology a nascent specialization during the 1940 s and 1950 - focused mostly on the part of the colonizer, searching and digging for the remains of first European settlement (e.g., Cruxent 1955, 1972; Goodwin 1946; de Hostos 1938; Palm 1945, 1952, 1955; Wing 1961) and drawing up descriptions and classifications of European artifacts (e.g., Goggin 196o, 1968; Lister and Lister 1974; Mendoza 1957; Rouse 1942). Paradoxically, indigenous-European interaction was observed

3 Historical developments in the field of Spanish colonial archaeology have followed a parallel pattern throughout the broader Caribbean region, including the adjacent parts of the continental coasts. Here, however, we take the insular Caribbean as our point of reference, as this is the area we work in and we know best. 
mainly through the haphazard recovery of Spanish artifacts and their purported indigenous modifications or imitations in sites previously identified as pre-Columbian. Such objects were not contemplated much other than being indications for barter or gift exchange (García Castañeda 1949; Morales Patiño and Pérez de Acevedo 1945; Rouse 1942). The methodology Quimby and Spoehr (1951) had used to measure culture change did not become as popular in the Caribbean as it had been in North America. Instead, the works that gained ground in the former region were those of anthropologists Fernando Ortiz (1995) and, later, George M. Foster (1960).

Ortiz' seminal work Cuban Counterpoint (published in Spanish in 1940, and in English in 1947 [1995]) was an effort to explain the creation of Cuban popular culture based on the historical roles of sugar and tobacco. In this study, he coined the term "transculturation" in direct opposition to the concept of acculturation. Changes resulting from culture contact, he argued, must be seen as the two-way adoption of elements from "the other." Beyond a mere acquisition, this process entails both the loss of traditional cultural expressions and the creation of new (blended) ones. Cuban archaeologists Oswaldo Morales Patiño and Roberto Pérez de Acevedo (1945) and José A. García Castañeda (1949) were the first to apply Ortiz' idea of transculturation as an analytical construct for the study of indigenous-European interaction. Although they did not appreciate the truly processual, transformative, and creative nature of the original concept (Valcárcel Rojas 2012, 32), their pioneering work served as an example for others in subsequent decades (e.g., García Arévalo 1978a; Guanche 1983; Rey Betancourt 1972; Romero 1981; see also Deagan 2010).

Foster's (1960) contribution can be found in his idea of "conquest culture," a concept he developed to understand culture change and colonial interaction in Mexico. The "donor" culture, he argued, only transfers to the "recipient" culture a selection of its culture traits and complexes, called "conquest culture," from which the latter adopts or rejects elements. This "stripped down" version comes about through two "screening processes," an initial "formal" one by the colonial power (directed policy) and a second "informal" one determined locally by the contact situation itself (founder's effect). In Foster's view, this filtering led to "cultural crystallization," when the "recipient" culture internalizes the new traits, with the acculturated society as final creation. Much of this process depends on the (differential) amount of power exercised by the dominant culture. Spanish colonial archaeologists widely adopted the model after 1970, especially since Kathleen A. Deagan $(1974,1983$, 1990) first applied it for her interpretation of archaeological patterns observed at St. Augustine, Florida (e.g., Ewen 1991; García Arévalo 1990; Smith 1995; see South 1978). 
In 1978, Cuban archaeologist Lourdes S. Domínguez synthesized prevailing ideas to come up with a methodology relating the distribution of Spanish artifacts in indigenous sites to patterns of interaction. To this end, she distinguished between "contact sites" and "transculturation sites" (Domínguez 1978, 37). A "contact site" points to short or indirect interaction, expressed by few and unmodified European objects scattered across the surface. A "transculturation site," in contrast, is identified through larger quantities of introduced materials, modified or reused for indigenous purposes, and occurring at deeper site levels, indicating more prolonged interaction and cultural exchange. The classification was important for offering an analytical tool for the archaeological understanding of indigenous-European interactions. During this time, also some of the first studies contemplating the indigenous use and valuation of Spanish artifacts appeared (García Arévalo 1978a; Vega 1987). Archaeological investigations into the period of indigenous-Spanish interaction increased over the years, although a strong focus on Spanish colonial spaces remained (for some examples from the Greater Antilles, see, e.g., Agorsah 1991; Curtin 1994; Domínguez 1984, 1991; Luna Calderón 1992; Ortega 1982; Ortega and Fondeur 1978; Pantel et al. 1988; but cf. Ortega 1988). These localities yielded various "transcultural" ceramics or "colonowares," referring to non-European and locally manufactured household vessels that combine both European and non-European stylistic and compositional elements (Domínguez 1980; García Arévalo 1978b, 1990, 1991; Ortega 1980; Ortega and Fondeur 1978; Woodward 2006). While these are typically blends of indigenous and European traditions, African-European or Creole ceramics have also been documented (Ernst 2015; Smith 1995; Solis Magaña 1999). Thus, observed changes in burial, culinary, and material practices created an interest in further exploring the transformations set in motion by the early colonial interactions. Although it was acknowledged, particularly in Cuba (Valcárcel Rojas 1997), that better-informed analyses needed new methodologies and research strategies, it was not until the 1990s that these started to come to fruition. It was only then that Spanish colonialera archaeology experienced a shift in orientation, discarding its ideology of dominance and unidirectionality. Largely in response to the emerging postmodern theories within the broader discipline, a more nuanced, inclusive, and local view of the early colonial period was sought (Keegan 1996; Patterson 1991; Wilson 1993; see also Van Buren 2010). Nowadays, the entangled and transformative nature of indigenous-European encounters has been widely acknowledged, and is considered the foundational bricks of the later colonial period and the postcolonial present. It is within this context that this volume is placed and aims to contribute. 
In late 1950s, Cruxent and Rouse (1958, I, 415) used the very first radiocarbon dates to define five arbitrary chronological periods for the history of the Southern Caribbean and the Venezuelan mainland; "Period 5" in this chronology lasted from 1500 onwards. A few years later, Rouse and Cruxent $(1963,22)$ defined four subsequent "epochs" connecting technology with subsistence strategies in Caribbean culture history, where the "Indo-Hispanic epoch" comprised the period from AD 1500 to the present. Later, Rouse $(1972,136-138)$ redefined the epochs in purely technological terms to "ages" where the "Historic Age" lasted from AD 1500 until the present. However, the "Indo-Hispanic" or "Historic Age" resulted in broad historical-cultural conceptualizations, which had to be challenged by future researchers whose aim was attaining more socially-tuned and spatially localized levels of understanding of the colonial past. In the insular Caribbean, the very early colonial period became equated with a so-called "Columbian era" or "contact period," a time frame of roughly two or three decades of indigenous-Spanish interaction following the arrival of Columbus (Deagan 1988; García Arévalo 1978a). Historically, the end of this period corresponds to the Spanish shift of attention to the Central American mainland. Moreover, it was wrongly believed that at this moment indigenous sociopolitical structures had disintegrated in the insular Caribbean and their numbers reduced to a negligible minimum. Nowadays we know, acknowledging the different colonial temporalities within and between islands, that this period lasted until the 1520 os or 1530 os in the Bahamas, Jamaica, and Puerto Rico, and the mid-sixteenth century for Cuba and Hispaniola (Valcárcel Rojas 2016, 11-12; see also Valcárcel Rojas 2012, 2016 for his conceptual application of distinguishing contact versus colonial situations in the Antillean context). Indigenous slavery and resistance, European colonization, and the influx of African slaves beginning in the sixteenth century led to the mixing of biological ancestries and the formation of new identities as well as social and material worlds (Deagan 2003; Jiménez 1986; Mira Caballos 1997). Indigenous peoples and indigenous traditions survived in this area until today, which ultimately contributed to the formation of present-day, multi-ethnic Caribbean society on these islands (García Molina et al. 2007; Guitar et al. 2006; Hofman 2019; Hofman et al. 2012; Pesoutova and Hofman 2016).

The indigenous presence clearly continues beyond the above-mentioned fifteenth- to eighteenth-century time slot. For example, by 1800 , the Carib presence in the Lesser Antilles was dramatically reduced, but the colonial encounters had resulted in new and unique social formations influenced by indigenous, European, and African cultural elements. Carib communities 
absorbed large numbers of escaped African slaves, leading to the formation of a Black Carib ethnic identity, alongside traditional Kalinago communities. After several wars with the British, many Black Carib were deported to Central America in 1797, where they are known as the Garifuna. Descendants of the Kalinago and Garifuna live throughout the Lesser Antilles where they reclaim their Amerindian roots as an integral part of their Caribbean identity. Based on this and many other similar examples known from across the Caribbean, the archeological sites and materials discussed in this volume rely on data that embody the wide range of fifteenth- through eighteenth-century processes of negotiation, exchange, hybridization, resignification and transformation, and resistance and struggle between the colonized and the colonizer. The case studies cover the circum-Caribbean macroregion and include the Bahamas, the Dominican Republic and Haiti (previously La Hispaniola), Jamaica, the southern Lesser Antilles, the Guianas, Venezuela, Colombia, San Salvador, Honduras, Belize, Guatemala, Mexico, and the American Southwest. Although this selection inevitably leaves out other parts and islands of our area of focus, we believe the case studies assembled here are representative of the colonial processes, initial European settlement, and Amerindian-European-African intercultural dynamics, we wish to explore with this contribution (Fig. 1.1).

It is important to delineate the place of this volume in the recently burgeoning archaeological scholarship on colonial encounters in the Americas. For centuries, a bricolage of facts and fiction have permeated the reconstruction of early colonial encounters and their later colonial trajectories in the Caribbean. Scholarly data has been freely incorporated into popular lore and contributed to the creation of grand narratives, which nourished literature and cinematography, and became an important cog in the creation of national identities throughout the entire region. However, these narratives continue the perpetuation of incomplete and unidirectional drifts in which, (1) Amerindian and African social actors are essentialized (portrayed distortedly) or invisible (lacking their place in history); (2) the materiality of colonial encounters has often been reduced to the mere description of indigenous versus European artifacts; and (3) the role of non-urban spaces in the re-organization of early colonial territories in the Caribbean has barely been investigated. Clearly, the role of archaeology in this scenario cannot lay only in nourishing the existing narratives. Because of new interdisciplinary field investigations, novel theoretical approaches, and cutting-edge methods and techniques, archaeology 


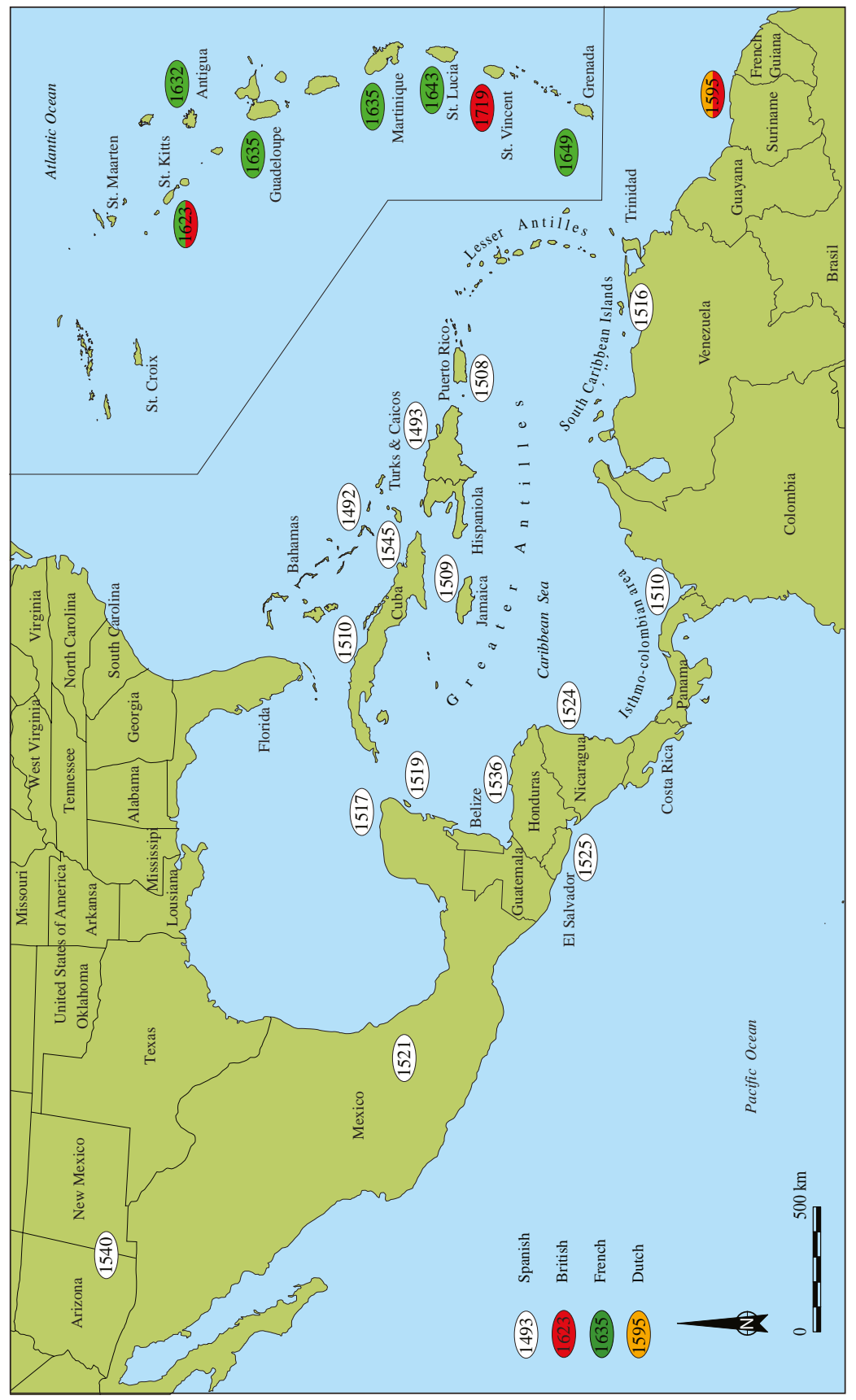

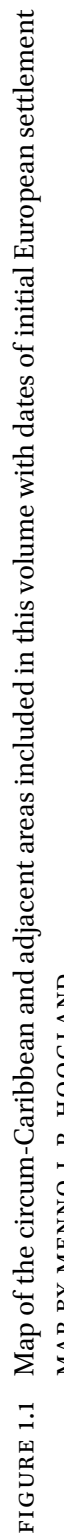


may amend and complement some of the narratives. But most importantly, it should critically evaluate, contest or replace them in constant interaction with, and sensitive to, the tensions of the globalizing world in and beyond the walls of academia. We are confident that this volume will contribute to this task by exploring early colonial encounters in the broader Caribbean region from a material culture perspective, one especially based on new field data.

In Chapter 2, Mary Jane Berman and Perry Gnivecki explore the first indigenous-Spanish encounters in the Bahama archipelago, a colonial frontier impacted by Spanish policies and practices during the late fifteenth and early sixteenth centuries. They argue that European objects, which made their way here through numerous pathways, were easily incorporated into the indigenous Lucayan economic system due to the precedents set by the Lucayan's familiarity with non-local items and peoples through trade, exchange, and raids. Additionally, the Lucayans found European objects to be analogous to materials they knew and understood and so they were easily assimilated into the local system. Berman and Gnivecki conclude that in the Bahamas the indigenous alteration of European objects was minimal because of the absence of direct colonial control, the short period of time during which the Lucayans were part of the Spanish empire, the sporadic and intermittent duration of direct contact experiences with the Spanish, and the way the Lucayans were removed from their homeland.

In Chapter 3 of this volume, Floris Keehnen discusses the cultural implications of European materials recovered from early colonial indigenous spaces on the island of Hispaniola, where during the late fifteenth- and early sixteenth-century indigenous and Spanish material worlds increasingly entangled. Reviewing more than fifty years of archaeological work on the island, Keehnen presents an up-to-date overview of indigenous sites yielding European or European-influenced objects. An examination of the recovered materials illustrates that these are found in a variety of contexts, range from singular finds to direct associations to indigenous valuables, and occasionally appear in reworked, repurposed, or copied forms. Through several case-study sites, Keehnen explores how the various ways in which indigenous peoples handled these European-introduced objects relates to the differential impacts of colonial power on Hispaniola.

Shea Henry and Robyn Woodward (Chapter 4) present novel data on their excavations at the indigenous village of Maima in Jamaica, which they compare with material culture and faunal remains from nearby Spanish Sevilla la Nueva. In June 1503, Columbus and his crewmembers spent a year marooned in the sheltered harbor of St. Ann's Bay, 1.4 kilometers from Maima. In 1509, the Spanish returned to find the Jamaican colonial capital of Sevilla la Nueva. 
By the time Sevilla la Nueva was abandoned in 1534, Maima was deserted. Historical records kept by the colonists indicate that the villagers were brought to the colony and made into laborers and wives. The material culture and dietary practices at Sevilla la Nueva reflect this through the presence of colonoware and indigenous-adapted European goods. Henry and Woodward observe that at Maima very few European goods and domesticate animals were found. They argue that this, and the presence of traditional material culture and diet throughout the site, indicates continuity of a traditional way of life until their final act of resistance, abandoning Maima.

In Chapter 5, Roberto Valcárcel Rojas focuses on northeastern Cuba, particularly the modern-day province of Holguín, which is one of the areas of the Caribbean with the largest number of indigenous sites yielding European objects. In the sixteenth century, most of these sites maintained direct or indirect links with Europeans, while others were transformed into permanent colonial spaces by the Spaniards. The study of European objects found at these sites suggests that some of these items were acquired through exchange or as gifts. However, as Valcárcel Rojas shows, the largest collections of objects appear to have originally functioned as tools or other items used by both Europeans and indigenous peoples for mining and agricultural labor. He proposes that this pattern was established as a result of a process of conquest and colonization specific to Cuba, during which European colonizers rapidly managed to control the local population, thus limiting the indigenous capacity for negotiation.

Marlieke Ernst and Corinne Hofman take us back to early colonial Hispaniola in Chapter 6, where they contrast the incorporation of European earthenwares in the indigenous sites of El Cabo and Playa Grande with the presence of indigenous ceramics and new manufacturing traditions in the early Spanish colonial sites of Cotuí and Concepción de la Vega. Using theories of gift giving, appropriation, and imitation, combined with archaeological and ethnoarchaeological studies of the operational sequence (chaîne opératoire) of ceramic manufacture, Ernst and Hofman specifically assess transformation processes in ceramic repertoires, providing new insights into the dynamics of indigenous-European-African interactions, mutual influences, and resilience.

In Chapter 7, Andrzej Antczak and colleagues delve into the early sixteenth century on the islands of Margarita, Coche, and Cubagua, which lay at the core of the so-called 'Coast of Pearls' in northeastern Venezuela. Cubagua has hosted Nueva Cádiz, one of the earliest Spanish towns in South America, since 1528. Despite such precocious credentials, the understanding of early colonial realities on these islands has almost entirely relied on documentary sources with only a small contribution from archaeology. By analyzing the ecology of the pearl oyster, documentary information, and archaeological data obtained 
in recent surveys on Margarita and Coche, from museum collections of materials recovered in the 1950s, and from the database of the Venezuelan Islands Archaeology project, Antczak and colleagues shed new light on the earliest colonial non-urban settlements or rancherías established on these islands and on the nature of the intercultural dynamics that took place there. They discuss specific sites on Margarita and Coche, which yielded abundant sixteenthcentury European ceramics, indigenous pottery, and possibly intercultural hybrids. Their findings allow Antczak and colleagues to provide new insights into the beginnings of the early Spanish town of Nueva Cádiz and underscore the role of pearls and other material culture in the early colonial endeavors in northeastern Venezuela.

Alberto Sarcina (Chapter 8) investigates the relationships between the indigenous peoples of the western region of the Gulf of Urabá, Colombia, and the Spaniards in the early years of the conquest. He focuses on what happened in Santa María de la Antigua del Darién, the first European city founded on the American mainland, in the course of its short history, and immediately after its abandonment (1510-1524). Sarcina offers new reflections on these questions, based on historical sources (Oviedo and the reports of the travels of Julian Gutiérrez) and archaeological data obtained during excavations carried out by the author between 2014 and 2016, which include ritual caches dated to the phase of the city's abandonment; "contact" pottery from the Basurero Norte area; and, "excavation unit F," a possible house inhabited by indigenous servants (naborías).

In the following Chapter 9, William Fowler and Jeb Card introduce the conquest-period and early colonial site of Ciudad Vieja, the ruins of the first villa of San Salvador, El Salvador, settled from 1525 to about 1550/6o. They evaluate subsequent developments from investigations of the indigenous town of Caluco, in the Izalcos region of western El Salvador, during the last quarter of the sixteenth century. A theoretical framework inspired by Bourdieu's structural theory of practice allows them to intepret differing strategies of practice during the early Spanish colonial period. Fowler and Card argue that the early "Spanish" community of San Salvador, potentially located on an already ancient Mesoamerican ritual site, was an incubator of experimentation and transformation of Mesoamerican roles and identities. They illustrate that by the time of Caluco's colonial community in the late sixteenth century, practices and structures found in later Latin American communities, built on tensions between indigenous communities and state extraction, were increasingly apparent.

In Chapter 10, Russell Sheptak and Rosemary Joyce emphasize the novel construction of defensive walls at Ticamaya, a pre-Columbian settlement 
in Caribbean Honduras that continued to be occupied into the nineteenth century, and at allied sites along the coast of the Gulf of Honduras as likely material traces of innovations mediated by Spanish knowledge mobilized for indigenous resistance to Spanish colonization. Archaeological excavations at Ticamaya, described in sixteenth-century Spanish documents as the seat of a leader of indigenous resistance, identified confirmed deposits from the period covering initial conflict with the Spanish, from roughly $15^{20}$ to 1536 . Yet, as Sheptak and Joyce demonstrate, these excavations produced no use of European goods until the late eighteenth century. Contemporary with Ticamaya, the site of Naco to the west hosted troops sent by Hernán Cortés, and at least one majolica vessel was discarded there. The contrast could lead to the conclusion that Ticamaya was unaffected by the Spanish encounter until it was incorporated into the colony. By considering apparently indigenous things as outcomes of tactical coping with Spanish invasion, Sheptak and Joyce seek to blur seemingly firm lines between native and foreign materialities and define a third option of hybrid cultures.

Jaime Awe and Christophe Helmke in Chapter 11 focus on the early MayaSpanish interactions in Belize. They note that researchers who have focused attention on the Belize colonial frontier describe Maya-Spanish relationships as anything but amicable. Because of this bellicose relationship, some authors suggest that few material goods of European origin were traded or integrated into frontier settlements. They also contend that while ethnohistoric reports describing the missionizing efforts of Spanish priests provide us with important data on Maya life during the early colonial period, the Spanish entradas provide precious little information about the material goods they gifted to the Maya, and even less about how the Maya utilized these foreign goods. In this chapter, Awe and Helmke discuss how the ethnohistoric record offers us considerable information concerning the consumption of European objects by the Maya, and that archaeological discoveries in Belize, Guatemala, and Yucatan provide increasing evidence to suggest that a variety of objects of European origin were integrated into Maya material culture. The archaeological record also indicates that, as Awe and Helmke show, objects of European origin were used as status symbols by the Maya elite, that they sometimes served mundane purposes, or were deposited in caches and offerings in sacred places where they were ritually decommissioned.

In Chapter 12, Shannon Dugan Iverson discusses archaeological assemblages from two early colonial religious sites at Tula, Hidalgo, Mexico. These assemblages are nearly indistinguishable from pre-Columbian ones at the same sites, indicating that, as Iverson argues, colonial changes in material culture were much more gradual than expected, and driven to a surprising degree by indigenous 
traditions and aesthetic choices. Taking these data into account, Iverson reconsiders various models of social change that would adequately account for the observations of material culture at Spanish religious sites. While documentary sources inform us that the colonial encounter was not an equal exchange of ideas, models of top-down power alone could not account for the data in Tula. Conversely, models that posited cultural continuity - an indigenous "core" with a Spanish colonial "veneer" - seemed inadequate to account for genuine indigenous relationships with the Church. Iverson uses the case of Tula to explore the legacies and problems of several models, including acculturation and syncretism, before positing Judith Butler's concept of resignification as an appropriate model of colonial power and religious change.

In Chapter 13, Gilda Hernández Sánchez presents insights into the process of indigenous cultural continuity and change by focusing on pottery technology in the region of central Mexico during the early colonial period (AD 1521-1650). Her analysis is based on the integration of previous research on ceramics, as well as on the consulting of several archaeological collections of early colonial ceramics from many contexts in the Valley of Mexico. Hernández-Sánchez shows that the collapse of the Aztec empire, the emergence of a new colonial society, and the introduction of Spanish ceramic traditions (e.g., potters' wheel, glazing, and majolica ware) differentially impacted the native production of ceramics. While clay recipes, method of forming, and firing technology were maintained without change, surface finishing and decoration evidenced great creativity, providing proof of indigenous peoples' varied responses and adaptations to the changing circumstances Spanish colonization had set in motion.

Clay Mathers argues in Chapter 14 that, although conflict and conquista campaigns characterized many of the earliest encounters between indigenous and European groups in New Spain and La Florida, the transformation of objects, communities, and strategic policies in these areas was locally variable and changed dramatically by the close of the sixteenth century. Mathers points out that materials characteristic of these changes and variegated responses are found widely in the archaeological record of the American Southwest, but have seldom been explored for the insights they provide into broader anthropological themes such as resistance, exchange, and agency. While Mathers focuses on the fine-grained, contextual analysis of objects, the broader goal of his contribution is to compare cultural trajectories at the regional and interregional scales, particularly the congruence and contrasts between the American Southwest and Southeast in the first century of New-Old World contact. Both areas transitioned from initial imperial strategies of acquisition and conflict, to policies of settlement and missionization by the end of the 16oos, and in 
both areas a similar suite of European objects was available. Nevertheless, as Mathers illustrates, the way these objects were employed by indigenous peoples and Europeans varies significantly and in ways that reveal to us important aspects of the earliest colonial encounters in North America.

In Chapter 15, Martijn van den Bel and Gérard Collomb argue that during the sixteenth century, the indigenous population of the Guianas was already aware of and in contact with the Spanish settlement at Margarita Island. The Aruacas, the privileged allies of the Spanish, relied on their large sociopolitical (trade) network to obtain victuals and commercial goods from the Guianas, but also raided Caribe villages to assure indigenous slaves for the Spanish plantations and mines in the insular Caribbean. Van den Bel and Collomb explain that although the indigenous peoples of the eastern Guianas feared and fled the Spanish and the Aruacas, they did engage in encounters with the English, Dutch, and French, in whom they found allies to wage war against their local and Spanish enemies. These encounters with Europeans, they point out, took place mainly in the embouchures of rivers along the Guiana Coast, establishing a 'zone franche' or socio-economical free zone. In this chapter, Van den Bel and Collomb focus upon the policies and alliances of the Yao of the Oyapock estuary, who, through their access of the interior, managed to control this coastal area.

Corinne Hofman and co-authors (Chapter 16) focus on the impacts of colonial encounters on indigenous Island Carib/Kalinago societies in the southern Lesser Antilles by studying transformations in settlement pattern and organization, material culture, and network strategies using historical information and new archaeological data. They present their results of the recent excavations at the early colonial sites of Argyle, St. Vincent, and La Poterie, Grenada, which have revealed the remains of indigenous villages and a set of material culture evidencing the first indigenous, European, and African interactions in this area. Hofman and colleagues advance novel perspectives on intercultural dynamics in colonial encounter situations and contribute to discussions of indigenous resistance, cultural transformations, and cultural diversity in an everglobalizing world.

In the epilogue, Maxine Oland brings closure to the volume by commenting on the contributions it brings to the understanding of the material encounters and indigenous transformations in the early colonial Americas and delineating the avenues for future research.

Considered together, these individual contributions are illustrative of the diversity, plurality, and complexity of early colonial situations in the Americas. With novel theoretical insights and fresh, interdisciplinary, and fine-grained views of local histories, the chapters offer new perspectives on materiality and 
indigenous agency in colonial encounters and entanglements. This volume highlights the importance of studying these issues in the Caribbean and surrounding mainland given the early dates of indigenous-European interactions and their foundational impact for the subsequent unfolding of colonial processes in the wider Americas. With this unique combination of geographical scope and approach, this volume contributes to the further decolonization of (indigenous) colonial histories and to global dialogues about the archaeology of colonialism.

\section{References}

Abu-Lughod,Janet L. 1989. Before European Hegemony:The World System A.D. 1250-1350. Oxford: Oxford University Press.

Agorsah, E. Kofi. 1991. "Recent Developments in Archaeological Research in Jamaica." In Proceedings of the 14th Congress of the International Association for Caribbean Archaeology, edited by Alissandra Cummins and Philippa King, 416-424. Barbados: The Barbados Museum and Historical Society.

Algaze, Guillermo. 1993. The Uruk World System: The Dynamics of Expansion of Early Mesopotamian Civilization, and ed. Chicago: University of Chicago Press.

Anderson-Córdova, Karen F. 2017. Surviving Spanish Conquest:Indian Fight, Flight, and Cultural Transformation in Hispaniola and Puerto Rico. Tuscaloosa: University of Alabama Press.

Atalay, Sonya. 2006. "Indigenous Archaeology as Decolonizing Practice." American Indian Quarterly 30 (3/4): 280-310.

Axtell, James. 1995. "Columbian Encounters: 1992-1995." The William and Mary Quarterly $5^{2}$ (4): 649-696.

Beals, Ralph. 1953. "Acculturation." In Anthropology Today: An Encyclopedic Inventory, edited by Alfred L. Kroeber, 621-641. Chicago: University of Chicago Press.

Bhabha, Homi K. 1994. The Location of Culture. London: Routledge.

Blanton, Richard and Gary Feinman. 1984. "The Mesoamerican World System." American Anthropologist 86 (3): 673-682.

Boomert, Arie. 2002. "Amerindian-European Encounters on and around Tobago (1498Ca. 1810)." Antropológica 97/98: 71-207.

Boomert, Arie. 2016. The Indigenous Peoples of Trinidad and Tobago: From the First Settlers until Today. Leiden: Sidestone Press.

Bourdieu, Pierre. 1977. Outline of a Theory of Practice. Cambridge: Cambridge University Press.

Braudel, Fernand. 1981. Civilization and Capitalism 15th-18th Century, Vol. 1: The Structures of Everyday Life. New York: Harper \& Row. 
Bray, Warwick, ed. 1993. The Meeting of Two Worlds: Europe and the Americas, 1492-1650. Proceedings of the British Academy, Volume 81. Oxford: Oxford University Press.

Bruchac, Margaret M., Siobhan M. Hart, and H. Martin Wobst. 2010. Indigenous Archaeologies: A Reader on Decolonization. Walnut Creek: Left Coast Press.

Card, Jeb J. 2013. The Archaeology of Hybrid Material Culture. Center for Archaeological Investigations Occasional Paper No. 39. Carbondale: Southern Illinois University Press.

Cipolla, Craig N., ed. 2017. Foreign Objects: Rethinking Indigenous Consumption in American Archaeology. Tucson: University of Arizona Press.

Cipolla, Craig N. and Katherine Howlett Hayes, eds. 2015. Rethinking Colonialism: Comparative Archaeological Approaches. Gainesville: University Press of Florida.

Cobb, Charles R., ed. 2003. Stone Tool Traditions in the Contact Era. Tuscaloosa: University of Alabama Press.

Comaroff, Jean. 1985. Body of Power, Spirit of Resistance: The Culture and History of a South African People. Chicago: University of Chicago Press.

Cooper, Jago, Marcos Martinón-Torres, and Roberto Valcárcel Rojas. 2008. “American Gold and European Brass: Metal Objects and Indigenous Values in the Cemetery of El Chorro de Maíta, Cuba." In Crossing the Borders: New Methods and Techniques in the Study of Archaeological Materials from the Caribbean, edited by Corinne L. Hofman, Menno L.P. Hoogland, and Annelou L. van Gijn, 34-42. Tuscaloosa: University of Alabama Press.

Crosby, Alfred W. 1972. The Columbian Exchange: Biological and Cultural Consequences of 1492. Westport: Greenwood.

Cruxent, José M. 1955. “Nueva Cádiz: Testimonio de Piedra." El Farol 159 (17): 2-5.

Cruxent, José M. 1972. "Algunas Noticias Sobre Nueva Cádiz (Isla de Cubagua), Venezuela." In Memorias VI Conferencia Geológica Del Caribe, Isla de Margarita, 6-14 July, 33-35. Caracas.

Cruxent, José M. and Irving B. Rouse. 1958. An Archaeological Chronology of Venezuela, Vol. 1 and 2. Social Sciences Monographs 6. Washington, DC: Pan American Union.

Curtin, Marguerite. 1994. "Carvings from New Seville." Jamaica Journal 25 (2): 19-23.

Cusick, James G., ed. 1998. Studies in Culture Contact: Interaction, Culture Change, and Archaeology. Occasional Paper No. 25. Carbondale: Center for Archaeological Investigations, Southern Illinois University.

Dawdy, Shannon Lee. 2000. "Understanding Cultural Change through the Vernacular: Creolization in Louisiana." Historical Archaeology 34 (3): 107-123.

Deagan, Kathleen A. 1974. "Sex, Status, and Role in the Mestizaje of Spanish Colonial Florida." PhD dissertation, University of Florida, Gainesville.

Deagan, Kathleen A. 1983. Spanish St. Augustine: The Archaeology of a Colonial Creole Community. New York: Academic Press. 
Deagan, Kathleen A. 1985. "Spanish-Indian Interaction in Sixteenth-Century Florida and Hispaniola." In The European Impact on Native Cultural Institutions in Eastern North America, A.D. 1000-180o, edited by William W. Fitzhugh, 281-318. Washington, DC: Smithsonian Institution Press.

Deagan, Kathleen A. 1987. "Initial Encounters: Arawak Responses to European Contact at the En Bas Saline Site, Haiti." In Proceedings of the ist San Salvador Conference: Columbus and His World, edited by Donald T. Gerace, 341-359. Fort Lauderdale: College Center of the Finger Lakes and San Salvador: Bahamian Field Station.

Deagan, Kathleen A. 1988. "The Archaeology of the Spanish Contact Period in the Caribbean." Journal of World Prehistory 2 (2): 187-233.

Deagan, Kathleen A. 1990. "Sixteenth-Century Spanish-American Colonization in the Southeastern United States and the Caribbean." In Columbian Consequences, Vol. 2: Archaeological and Historical Perspectives on the Spanish Borderlands East, edited by David Hurst Thomas, 225-250. Washington, DC: Smithsonian Institution Press.

Deagan, Kathleen A. 1996. "Colonial Transformation: Euro-American Cultural Genesis in the Early Spanish-American Colonies." Journal of Anthropological Research $5^{2}$ (2): 135-16o.

Deagan, Kathleen A. 1998. "Transculturation and Spanish American Ethnogenesis: The Archaeological Legacy of the Quincentenary." In Studies in Culture Contact: Interaction, Culture Change, and Archaeology, edited by James G. Cusick, 23-43. Occasional Paper No. 25. Carbondale: Center for Archaeological Investigations, Southern Illinois University.

Deagan, Kathleen A. 2003. "Colonial Origins and Colonial Transformations in Spanish America." Historical Archaeology 37 (4): 3-13.

Deagan, Kathleen A. 2004. "Reconsidering Taíno Social Dynamics after Spanish Conquest: Gender and Class in Culture Contact Studies." American Antiquity 69 (4): $597-626$.

Deagan, Kathleen A. 2010. "Cuba and Florida: Entwined Histories of Historical Archaeologies." In Beyond the Blockade: New Currents in Cuban Archaeology, edited by Susan Kepecs, L. Antonio Curet, and Gabino La Rosa Corzo, 16-25. Tuscaloosa: University of Alabama Press.

Deetz, James. 1996. In Small Things Forgotten: An Archaeology of Early American Life. Expanded and revised edition. Garden City: Doubleday.

Delle, James A. 2000. "The Material and Cognitive Dimensions of Creolization in Nineteenth-Century Jamaica." Historical Archaeology 34 (3): 56-72.

Dietler, Michael. 2010. Archaeologies of Colonialism: Consumption, Entanglement, and Violence in Ancient Mediterranean France. Berkeley: University of California Press.

Domínguez, Lourdes S. 1978. "La Transculturación En Cuba (S. XVI-XVII)." Cuba Arqueológica 1: 33-50. 
Domínguez, Lourdes S. 1980. "Cerámica Transcultural En El Sitio Colonial Casa de La Obrapía." In Cuba Arqueológica II, edited by Manuel Rivero de la Calle, 15-26. Santiago de Cuba: Editorial Oriente.

Domínguez, Lourdes S. 1984. Arqueología Colonial Cubana: Dos Estudios. Havana: Editorial de Ciencias Sociales.

Domínguez, Lourdes S. 1991. Arqueología Del Centro-Sur de Cuba. Havana: Editorial Academia.

Elliott, John H. 2002. Imperial Spain, 1469-1716. London: Penguin.

Ernst, Marlieke. 2015. “(Ex)Changing the Potter's Process: Continuity and Change in the Non-European Ceramics of Cotuí, the First Colonial Mine in Hispaniola, after 1505." Research Master thesis, Leiden University.

Ernst, Marlieke and Corinne L. Hofman. 2015. "Shifting Values: A Study of Early European Trade Wares in the Amerindian Site of El Cabo, Eastern Dominican Republic." In GlobalPottery 1: Historical Archaeology and Archaeometry for Societies in Contact, edited by Jaume Buxeda i Garrigós, Marisol Madrid i Fernández, and Javier Garcia Iñañez, 195-204. Oxford: British Archaeological Reports, International Series 2761 .

Ewen, Charles R. 1991. From Spaniard to Creole: The Archaeology of Cultural Formation at Puerto Real, Haiti. Tuscaloosa: University of Alabama Press.

Ewen, Charles R. 2000. "From Colonists to Creole: Archaeological Patterns of Spanish Colonization in the New World." Historical Archaeology 34 (3): 36-45.

Ewen, Charles R. 2001. "Historical Archaeology in the Colonial Spanish Caribbean." In Island Lives: Historical Archaeologies of the Caribbean, edited by Paul Farnsworth, 3-20. Tuscaloosa: University of Alabama Press.

Farnsworth, Paul. 1989. "The Economics of Acculturation in the Spanish Missions of Alta California." Research in Economic Anthropology 11: 217-249.

Farnsworth, Paul. 1992. "Missions, Indians, and Cultural Continuity." Historical Archaeology 26 (1): 22-36.

Ferguson, Leland. 1992. Uncommon Ground: Archaeology and Early African America, 1650-180o. Washington D.C.: Smithsonian Institution Press.

Fernández-Armesto, Felipe. 1987. Before Columbus: Exploration and Colonisation from the Mediterranean to the Atlantic, 1229-1492. London: Macmillan.

Ferris, Neal. 2009. The Archaeology of Native-Lived Colonialism: Challenging History in the Great Lakes. Tucson: University of Arizona Press.

Ferris, Neal, Rodney Harrison, and Michael V. Wilcox. 2014. Rethinking Colonial Pasts through Archaeology. Oxford: Oxford University Press.

Fitzhugh, William W. 1985. "Early Contacts North of Newfoundland before A.D. 160o: A Review." In Cultures in Contact: The Impact of European Contacts on Native Cultural Institutions in Eastern North America, A.D. 1000-180o, edited by William W. Fitzhugh, 23-43. Washington, DC: Smithsonian Institution Press. 
Foster, George M. 196o. Culture and Conquest: America's Spanish Heritage. Viking Fund Publications in Anthropology 27. New York: Wenner-Gren Foundation.

Frank, André Gunder. 1966. "The Development of Underdevelopment." Monthly Review 18: $17-31$.

Funari, Pedro P.A. and Maria X. Senatore, eds. 2015. Archaeology of Culture Contact and Colonialism in Spanish and Portuguese America. Cham: Springer.

García Arévalo, Manuel A. 1978a. "La Arqueología Indo-Hispana En Santo Domingo." In Unidad YVariedad: Ensayos Antropológicos En Homenaje a José M. Cruxent, edited by Erika Wagner and Alberta Zucchi, 77-127. Caracas: Instituto Venezolano de Investigaciones Científicas.

García Arévalo, Manuel A. 1978b. "Influencias de La Dieta Indo-Hispanica En La Cerámica Taína." In Proceedings of the 7 th International Congress for the Study of the Pre-Columbian Cultures of the Lesser Antilles, edited by Ripley P. Bullen, 263-277. Montreal: Centre de Recherches Caraïbes, Université de Montréal.

García Arévalo, Manuel A. 1990. "Transculturation in Contact Period and Contemporary Hispaniola." In Columbian Consequences, Vol. 2: Archaeological and Historical Perspectives on the Spanish Borderlands East, edited by David Hurst Thomas, 269-28o. Washington, DC: Smithsonian Institution Press.

García Arévalo, Manuel A. 1991. "Influencias Hispánicas En La Alfarería Taína." In Proceedings of the 13th Congress of the International Association for Caribbean Archaeology Part 1, edited by Edwin N. Ayubi and Jay B. Haviser, 363-383. Willemstad, Curaçao: Archaeological-Anthropological Institute of the Netherlands Antilles.

García Castañeda, José A. 1949. "La Transculturación Indo-Española En Holguín." Revista de Arqueología YEtnología 8/9: 195-205.

García Molina, José A., Mercedes Garrido Mazorra, and Daisy Fariñas Gutiérrez. 2007. Huellas Vivas Del Indocubano. Havana: Editorial de Ciencias Sociales.

Giddens, Anthony. 1979. Central Problems in Social Theory: Action, Structure, and Contradiction in Social Analysis. London: Palgrave Macmillan.

Given, Michael. 2004. The Archaeology of the Colonized. London: Routledge.

Goggin, John M. 196o. The Spanish Olive Jar: An Introductory Study. New Haven: Department of Anthropology, Yale University.

Goggin, John M. 1968. Spanish Majolica in the New World: Types of the Sixteenth to Eighteenth Centuries. New Haven: Department of Anthropology, Yale University.

Goodwin, William B. 1946. Spanish and English Ruins in Jamaica. Boston: Meador.

Gosden, Chris. 2004. Archaeology and Colonialism: Cultural Contact from 5000 BC to the Present. Cambridge: Cambridge University Press.

Graeber, David. 1996. "Beads and Money: Notes Toward a Theory of Wealth and Power." American Ethnologist 23 (1): 4-24.

Graham, Elizabeth A. 2011. Maya Christians and Their Churches in Sixteenth-Century Belize. Gainesville: University Press of Florida. 
Greenblatt, Stephen. 1991. Marvelous Possessions: The Wonder of the New World. Chicago: University of Chicago Press.

Greenblatt, Stephen, ed. 1993. New World Encounters. Berkeley: University of California Press.

Guanche, Juan. 1983. Procesos Étnoculturales En Cuba. Havana: Ediciones Letros de Cubanos.

Guitar, Lynne, Pedro Ferbel-Azcarate, and Jorge Estevez. 2006. "Ocama-Daca Taíno (Hear Me, I Am Taíno): Taíno Survival on Hispaniola, Focusing on the Dominican Republic." In Indigenous Resurgence in the Contemporary Caribbean: Amerindian Survival and Revival, edited by Maximilian C. Forte, 41-67. New York: Peter Lang.

Hall, Stuart. 1990. "Cultural Identity and Diaspora." In Identity: Community, Culture, Difference, edited by Jonathan Rutherford, 222-237. London: Lawrence and Wishart.

Hall, Thomas D. and Christopher Chase-Dunn. 1993. "The World-Systems Perspective and Archaeology: Forward into the Past." Journal of Archaeological Research 1 (2): 121-43.

Hannerz, Ulf. 1987. “The World in Creolisation.” Africa 57 (4):546-559.

Hernández Mora, Iosvany. 2011. "La Arqueología Del Período Colonial En Cuba: Apuntes Teóricos de Sus Primeros Cincuenta Años (Parte I)." El Caribe Arqueológico 12: 3-14.

Herskovits, Melville J. 1938. Acculturation: The Study of Culture Contact. New York: Augustin.

Hill, Jonathan D. 1996. History, Power, and Identity: Ethnogenesis in the Americas, 1492-1992. Iowa City: University of Iowa Press.

Hofman, Corinne L. 2019. "Indigenous Caribbean Networks in a Globalizing World." In Power, Political Economy, and Historical Landscapes of the Modern World: Interdisciplinary Perspectives, edited by Christopher R. DeCorse, 55-80. Fernand Braudel Center studies in historical social science, SUNY press.

Hofman, Corinne L., Gareth R. Davies, Ulrik Brandes, and Willem J.H. Willems. 2012. "ERC Synergy Grant 2012, Research Proposal. NEXUS1492: New World Encounters in a Globalising World." Leiden: Leiden University.

Hofman, Corinne L., Angus A.A. Mol, Menno L.P. Hoogland, and Roberto Valcárcel Rojas. 2014. "Stage of Encounters: Migration, Mobility and Interaction in the Pre-Colonial and Early Colonial Caribbean." World Archaeology 46 (4): 590-6o9.

Hofman, Corinne L., Jorge Ulloa Hung, Eduardo Herrera Malatesta, Joseph Sony Jean, and Menno L.P. Hoogland. 2018. "Indigenous Caribbean Perspectives: Archaeologies and Legacies of the First Colonized Region in the New World." Antiquity 92 (361): 200-216.

Hostos, Adolfo de. 1938. Investigaciones Históricas. San Juan: Gobierno de Puerto Rico, Oficina del Historiador.

Hulme, Peter. 1986. Colonial Encounters: Europe and the Native Caribbean, 1492-1797. Cambridge: Cambridge University Press. 
Ibarra Rojas, Eugenia. 2003. "Gold in the Everyday Lives of Indigenous Peoples of Sixteenth-Century Southern Central America." In Gold and Power in Ancient Costa Rica, Panama, and Colombia, edited by Jeffrey Quilter and John W. Hoopes, 383-419. Washington, DC: Dumbarton Oaks.

Jansen, Maarten E.R.G.N. and Valentina Raffa, eds. 2015. Tiempo Y Comunidad: Herencias E Interacciones Socioculturales En Mesoamérica Y Occidente. Archaeological Studies Leiden University 29. Leiden: Leiden University Press.

Jiménez, G., A. Morella 1986. La Esclavitud Indígena En Venezuela (Siglo XVI). Caracas: Academia Nacional de la Historia.

Keegan, William F. 1996. "West Indian Archaeology. 2. After Columbus." Journal of Archaeological Research 4 (4): 265-294.

Keehnen, Floris W.M. 2011. "Conflicting Cosmologies: The Exchange of Brilliant Objects between the Taíno of Hispaniola and the Spanish." In Communities in Contact: Essays in Archaeology, Ethnohistory \& Ethnography of the Amerindian CircumCaribbean, edited by Corinne L. Hofman and Anne Van Duijvenbode, 253-268. Leiden: Sidestone Press.

Keehnen, Floris W.M. 2012. "Trinkets (f)or Treasure? The Role of European Material Culture in Intercultural Contacts in Hispaniola during Early Colonial Times.” Research Master thesis, Leiden University.

Keehnen, Floris W.M. and Angus A.A. Mol. 2018. "The Roots of the Columbian Exchange: An Entanglement and Network Approach to Early Caribbean Encounter Transactions." Unpublished manuscript, Faculty of Archaeology, Leiden University. Kroeber, Alfred L. 1948. Anthropology. New York: Harcourt, Brace \& Company.

Liebmann, Matthew. 2015. "The Mickey Mouse Kachina and Other 'Double Objects': Hybridity in the Material Culture of Colonial Encounters." Journal of Social Archaeology 15 (3): 319-341.

Liebmann, Matthew and Melissa S. Murphy, eds. 2011. Enduring Conquests: Rethinking the Archaeology of Resistance to Spanish Colonialism in the Americas. Santa Fe: School for Advanced Research Press.

Lightfoot, Kent G. 1995. "Culture Contact Studies: Redefining the Relationship between Prehistoric and Historical Archaeology." American Antiquity 6o (2): 199-217.

Lightfoot, Kent G., Antoinette Martinez, and Ann M. Schiff. 1998. "Daily Practice and Material Culture in Pluralistic Social Settings: An Archaeological Study of Culture Change and Persistence from FortRoss, California." AmericanAntiquity63(2):199-222.

Lister, Florence C. and Robert H. Lister. 1974. "Maiolica in Colonial Spanish America." Historical Archaeology 8 (1): 17-52.

Loren, Diana DiPaolo. 2008. In Contact: Bodies and Spaces in the Sixteenth- and Seventeenth-Century Eastern Woodlands. Lanham: AltaMira Press.

Loren, Diana DiPaolo. 2010. "The Exotic in Daily Life: Trade and Exchange in Historical Archaeology." In Trade and Exchange: Archaeological Studies from History and 
Prehistory, edited by Carolyn D. Dillian and Carolyn L. White, 195-204. New York: Springer.

Luna Calderón, Fernando. 1992. La Isabela. Primer Cementerio Indohispano En El Nuevo Mundo. Manuscript on file, Museo del Hombre Dominicano, Santo Domingo.

Lyons, Claire L. and John K. Papadopoulos. 2002. The Archaeology of Colonialism. Los Angeles: Getty Research Institute.

Maran, Joseph and Philipp W. Stockhammer, eds. 2012. Materiality and Social Practice: Transformative Capacities of Intercultural Encounters. Oxford: Oxbow Books.

McNiven, Ian J. 2016. "Theoretical Challenges of Indigenous Archaeology: Setting an Agenda." American Antiquity 81 (1): 27-41.

Mendoza, Lourdes C. 1957. "Cerámica de Las Ruinas de La Vega Vieja." Casas Reales 11: 101-113.

Mintz, Sidney W. and Richard Price. 1992. The Birth of African American Culture. Boston: Beacon.

Mira Caballos, Esteban. 1997. El Indio Antillano:Repartimiento, Encomienda Y Esclavitud (1492-1542). Seville: Muñoz Moya.

Mol, Angus A.A. 2008. "Universos Socio-Cósmicos En Colisión: Descripciones Etnohistóricas de Situaciones de Intercambio En Las Antillas Mayores Durante El Período de Proto-Contacto." El Caribe Arqueológico 10: 13-22.

Moore, John H. 1994. "Ethnogenetic Theory." Research and Exploration 10 (1): 10-23.

Morales Patiño, Oswaldo, and Roberto Pérez de Acevedo. 1945. "El Período de Transculturación Indo-Hispánica." Contribuciones Del Grupo Guama. Revista de Arqueología YEtnología 4/6:5-36.

Morsink, Joost. 2015. "Spanish-Lucayan Interaction: Continuity of Native Economies in Early Historic Times." Journal of Caribbean Archaeology 15: 102-119.

Murray, Tim, ed. 2004. The Archaeology of Contact in Settler Societies. Cambridge: Cambridge University Press.

Oland, Maxine. 2014. 'With the Gifts and Good Treatment That He Gave Them': Elite Maya Adoption of Spanish Material Culture at Progresso Lagoon, Belize." International Journal of Historical Archaeology 18 (4): 643-667.

Oland, Maxine, Siobhan M. Hart, and Liam Frink, eds. 2012. Decolonizing Indigenous Histories: Exploring Prehistoric/Colonial Transitions in Archaeology. Tucson: University of Arizona Press.

Oliver, José R. 200o. "Gold Symbolism among Caribbean Chiefdoms: Of Feathers, Çibas and Guanín Power among Taíno Elites." In Precolumbian Gold: Technology, Style and Iconography, edited by Colin McEwan, 196-219. London: British Museum Press.

Oliver, José R. 2009. Caciques and Cemí Idols: The Web Spun by Taíno Rulers Between Hispaniola and Puerto Rico. Tuscaloosa: University of Alabama Press.

Ortega, Elpidio J. 1980. Introducción a La Loza Común O Alfarería En El Período Colonial de Santo Domingo. Santo Domingo: Fundación Ortega Álvarez. 
Ortega, Elpidio J. 1982. Arqueología Colonial En Santo Domingo. Santo Domingo: Taller.

Ortega, Elpidio J. 1988. La Isabela Y La Arqueología En La Ruta de Colón. San Pedro de Macorís: Universidad Central del Este.

Ortega, Elpidio J. and Carmen G. Fondeur. 1978. Estudio de La Cerámica Del Período Indo-Hispana de La Antigua Concepción de La Vega. Santo Domingo: Taller.

Ortiz, Fernando. 1995. Cuban Counterpoint: Tobacco and Sugar. Durham: Duke University Press.

Ostapkowicz, Joanna. 2013. "Made ... With Admirable Artistry': The Context, Manufacture and History of a Taíno Belt." The Antiquaries Journal 93: 287-317.

Pagden, Anthony. 1993. European Encounters with the New World: From Renaissance to Romanticism. New Haven: Yale University Press.

Palm, Edward W. 1945. "Excavations at La Isabela, White Man's First Town in the Americas." Acta Americana 3: 298-303.

Palm, Edward W. 1952. "La Fortaleza de La Concepción de La Vega." In Memoria Del V Congreso Histórico Municipal Interamericano, 2: 115-118. Santo Domingo: Editora del Caribe.

Palm, Edward W. 1955. Los Monumentos Arquitectónicos de La Española. Vol. 1 \& 2. Santo Domingo: Universidad de Santo Domingo.

Palmié, Stephan. 1995. “Against Syncretism: 'Africanizing' and 'Cubanizing' Discourses in North American Òrìsa Worship.” In Counterworks: Managing of the Diversity of Knowledge, edited by Richard Fardon, 73-104. London: Routledge.

Pantel, A. Gus, Jalil Sued Badillo, Anibal Sepúlveda, and Beatriz del Cueto de Pantel. 1988. Archaeological, Architectural and Historical Investigations of the First Spanish Settlement in Puerto Rico: Caparra. Manuscript on file. The Foundation of Archaeology, Anthropology and History of Puerto Rico, San Juan.

Pasztory, Esther. 2005. Thinking with Things: Toward a New Vision of Art. Austin: University of Texas Press.

Patterson, Thomas C. 1991. "Early Colonial Encounters and Identities in the Caribbean: A Review of Some Recent Works and Their Implications.” Dialectical Anthropology $16(1): 1-13$.

Pesoutova, Jana and Corinne L. Hofman. 2016. "La Contribución Indígena a La Biografía Del Paisaje Cultural de La República Dominicana: Una Revisión Preliminar.” In Indígenas E Indios En El Caribe: Presencia, Legado Y Estudio, edited by Jorge Ulloa Hung and Roberto Valcárcel Rojas, $15^{-150}$. Santo Domingo: Instituto Tecnológico de Santo Domingo.

Pugh, Timothy W. 2009. "Contagion and Alterity: Kowoj Maya Appropriations of European Objects.” American Anthropologist 111 (3): 373-386.

Quimby, George I., and Alexander Spoehr. 1951. "Acculturation and Material Culture-I." Fieldiana - Anthropology 36 (6): 107-147. 
Ramenofsky, Ann F. 1987. Vectors of Death: The Archaeology of European Contact. Albuquerque: University of New Mexico Press.

Redfield, Robert, Ralph Linton, and Melville J. Herskovits. 1936. "Memorandum for the Study of Acculturation." American Anthropologist 38 (1): 149-152.

Rey Betancourt, Estrella. 1972. La Transculturación Indohispánica En Cuba. Serie Histórica 3. Havana: Academia de Ciencias de Cuba.

Richard, François G., ed. 2015. Materializing Colonial Encounters: Archaeologies of African Experience. New York: Springer.

Rodríguez-Alegría, Enrique. 2008. "Narratives of Conquest, Colonialism, and CuttingEdge Technology." American Anthropologist 110 (1): 33-43.

Rodríguez-Alegría, Enrique. 2010. "Incumbents and Challengers: Indigenous Politics and the Adoption of Spanish Material Culture in Colonial Xaltocan, Mexico." Historical Archaeology 44 (2): 51-71.

Rodríguez-Alegría, Enrique. 2016. The Archaeology and History of Colonial Mexico: Mixing Epistemologies. Cambridge: Cambridge University Press.

Rogers, J. Daniel. 1990. Objects of Change: The Archaeology and History of Arikara Contact with Europeans. Washington, DC: Smithsonian Institution Press.

Rogers, J. Daniel. 1993. "The Social and Material Implications of Contact on the Northern Plains." In Ethnohistory and Archaeology: Approaches to Postcontact Change in the Americas, edited by J. Daniel Rogers and Samuel M. Wilson, 73-88. New York: Plenum Press.

Rogers, J. Daniel and Samuel M. Wilson, eds. 1993. Ethnohistory and Archaeology: Approaches to Postcontact Change in the Americas. New York: Plenum Press.

Romero, Leandro E. 1981. "Sobre Las Evidencias Arqueológicas de Contacto YTransculturación En El Ámbito Cubano." Santiago 44: 77-108.

Rothschild, Nan A. 2003. Colonial Encounters in a Native American Landscape: The Spanish and the Dutch in North America. Washington, DC: Smithsonian Institution Press.

Rothschild, Nan A. 2006. "Colonialism, Material Culture, and Identity in the Rio Grande and Hudson River Valleys." International Journal of Historical Archaeology 10 (1): $73-108$.

Rouse, Irving B. 1942. Archaeology of the Maniabón Hills, Cuba. Yale University Publications in Anthropology 26. New Haven: Yale University Press.

Rouse, Irving B. 1972. An Introduction to Prehistory: A Systematic Approach. New York: McGraw-Hill.

Rouse, Irving B. and José M. Cruxent. 1963. Venezuelan Archaeology. New Haven: Yale University Press.

Rubertone, Patricia E. 1996. "Matters of Inclusion: Historical Archaeology and Native Americans." World Archaeological Bulletin 7: 77-86.

Rubertone, Patricia E. 2000. "The Historical Archaeology of Native Americans." Annual Review of Anthropology 29 (1): 425-446. 
Sahlins, Marshall D. 1976. Culture and Practical Reason. Chicago: University of Chicago Press.

Said, Edward W. 1978. Orientalism. New York: Pantheon Books.

Saunders, Nicholas J. 1999. "Biographies of Brilliance: Pearls, Transformations of Matter and Being, C. AD 1492." World Archaeology 31 (2): 243-257.

Scaramelli, Franz and Kay Tarble de Scaramelli. 2005. "The Roles of Material Culture in the Colonization of the Orinoco, Venezuela." Journal of Social Archaeology 5 (1): $135^{-168 .}$

Scheiber, Laura L. and Mark D. Mitchell, eds. 2010. Across a Great Divide: Continuity and Change in Native North American Societies, 1400-1900. Tucson: University of Arizona Press.

Schneider, Jane. 1977. "Was There a Pre-Capitalist World System?" Peasant Studies 6 (1): 20-29.

Silliman, Stephen W. 2005. "Culture Contact or Colonialism? Challenges in the Archaeology of Native North America." American Antiquity 70 (1):55-74.

Silliman, Stephen W. 2009. "Change and Continuity, Practice and Memory: Native American Persistence in Colonial New England." American Antiquity 74 (2): 211-230.

Silliman, Stephen W. 2010. "Indigenous Traces in Colonial Spaces: Archaeologies of Ambiguity, Origin, and Practice." Journal of Social Archaeology 10 (1):28-58.

Silliman, Stephen W. 2012. "Between the Longue Durée and the Short Pureé: Postcolonial Archaeologies of Indigenous History in Colonial North America." In Decolonizing Indigenous Histories: Exploring Prehistoric/Colonial Transitions in Archaeology, edited by Maxine Oland, Siobhan M. Hart, and Liam Frink, 113-132. Tucson: University of Arizona Press.

Silliman, Stephen W. 2015. “A Requiem for Hybridity? The Problem with Frankensteins, Purées, and Mules." Journal of Social Archaeology 15 (3): 277-298.

Silliman, Stephen W. 2016. "Disentangling the Archaeology of Colonialism and Indigeneity." In Archaeology of Entanglement, edited by Lindsay Der and Francesca Fernandini, 31-48. Walnut Creek: Left Coast Press.

Smith, Claire and H. Martin Wobst, eds. 2005. Indigenous Archaeologies: Decolonizing Theory and Practice. London: Routledge.

Smith, Greg C. 1995. “Indians and Africans at Puerto Real: The Ceramic Evidence." In Puerto Real: The Archaeology of a Sixteenth-Century Spanish Town in Hispaniola, edited by Kathleen A. Deagan, 335-374. Gainesville: University of Florida Press.

Solis Magaña, Carlos. 1999. "Criollo Pottery from San Juan de Puerto Rico." In African Sites Archaeology in the Caribbean, edited by Jay Haviser, 131-141. Princeton: Markus Weiner.

South, Stanley. 1978. "Pattern Recognition in Historical Archaeology." American Antiquity 43 (2): 223-230.

Spicer, Edward H., ed. 1961. Perspectives in American Indian Culture Change. Chicago: University of Chicago Press. 
Stein, Gil J., ed. 2005. The Archaeology of Colonial Encounters: Comparative Perspectives. Santa Fe: School of American Research Press.

Stewart, Charles and Rosalind Shaw, eds. 1994. Syncretism/Anti-Syncretism: The Politics of Religious Synthesis. London: Routledge.

Thomas, David Hurst, ed. 1989. Columbian Consequences, Vol. 1: Archaeological and Historical Perspectives on the Spanish Borderlands West. Washington, DC: Smithsonian Institution Press.

Thomas, David Hurst, ed. 1990. Columbian Consequences, Vol. 2: Archaeological and Historical Perspectives on the Spanish Borderlands East. Washington, DC: Smithsonian Institution Press.

Thomas, David Hurst, ed. 1991. Columbian Consequences, Vol. 3: The Spanish Borderlands in Pan-American Perspective. Washington, DC: Smithsonian Institution Press.

Thomas, Nicholas. 1991. Entangled Objects: Exchange, Material Culture and Colonialism in the Pacific. Cambridge: Harvard University Press.

Torrence, Robin and Anne Clarke, eds. 200o. The Archaeology of Difference: Negotiating Cross-Cultural Engagements in Oceania. London: Routledge.

Trigger, Bruce G. 1991. "Early Native North American Response to European Contact: Romantic versus Rationalistic Interpretations." The Journal of American History 77 (4): $1195^{-1215}$.

Valcárcel Rojas, Roberto. 1997. "Introducción a La Arqueología Del Contacto IndoHispánico En La Provincia de Holguín, Cuba." El Caribe Arqueológico 2: 64-77.

Valcárcel Rojas, Roberto. 2012. "Interacción Colonial en Un Pueblo de Indios Encomendados: El Chorro de Maíta, Cuba." PhD diss., Leiden University.

Valcárcel Rojas, Roberto. 2016. Archaeology of Early Colonial Interaction at El Chorro de Maíta, Cuba. Gainesville: University of Florida Press.

Valcárcel Rojas, Roberto, Marcos Martinón-Torres, Jago Cooper, and Thilo Rehren. 2010. "Turey Treasure in the Caribbean: Brass and Indo-Hispanic Contact at El Chorro de Maíta, Cuba." In Beyond the Blockade: New Currents in Cuban Archaeology, edited by Susan Kepecs, L. Antonio Curet, and Gabino La Rosa Corzo, 106-125. Tuscaloosa: University of Alabama Press.

Valcárcel Rojas, Roberto, Alice V.M. Samson, and Menno L.P. Hoogland. 2013. "IndoHispanic Dynamics: From Contact to Colonial Interaction in the Greater Antilles." International Journal of Historical Archaeology 17 (1): 18-39.

Van Buren, Mary. 2010. "The Archaeological Study of Spanish Colonialism in the Americas." Journal of Archaeological Research 18: 151-201.

Van Dommelen, Peter. 2006. "Colonial Matters: Material Culture and Postcolonial Theory in Colonial Situations." In Handbook of Material Culture, edited by Chris Tilley, Webb Keane, Susanne Küchler, Michael Rowlands, and Patricia Spyer, 104124. London: Sage Publications. 
Vega, Bernardo. 1979. Los Metales Y Los Aborígenes de La Hispaniola. Santo Domingo: Museo del Hombre Dominicano.

Vega, Bernardo. 1987. Santos, Shamanes YZemíes. Santo Domingo: Fundación Cultural Dominicana.

Voss, Barbara L. 2015. "Narratives of Colonialism, Grand and Not So Grand: A Critical Reflection on the Archaeology of the Spanish and Portuguese Americas." In Archaeology of Culture Contact and Colonialism in Spanish and Portuguese America, edited by Pedro P.A. Funari and Maria X. Senatore, 353-361. Cham: Springer.

Voss, Barbara L., and Eleanor Conlin Casella. 2012. The Archaeology of Colonialism: Intimate Encounters and Sexual Effects. Cambridge: Cambridge University Press.

Wallerstein, Immanuel M. 1974. The Modern World-System, Vol. I: Capitalist Agriculture and the Origins of the European World-Economy in the Sixteenth Century. New York: Academic Press.

Wallerstein, Immanuel M. 1980. The Modern World-System, Vol. II:Mercantilism and the Consolidation of the European World-Economy, 1600-1750. New York: Academic Press.

Whitehead, Neil L. 2011. "Native Americans and Europeans: Early Encounters in the Caribbean and along the Atlantic Coast." In The Oxford Handbook of the Atlantic World: $145^{-1850}$, edited by Nicholas Canny and Philip Morgan, 55-70. Oxford: Oxford University Press.

Williamson, Christine. 2004. "Contact Archaeology and the Writing of Aboriginal History." In The Archaeology of Contact in Settler Societies, edited by Tim Murray, 176-199. Cambridge: Cambridge University Press.

Wilson, Samuel M. 1990. Hispaniola: Caribbean Chiefdoms in the Age of Columbus. Tuscaloosa: University of Alabama Press.

Wilson, Samuel M. 1993. "Structure and History: Combining Archaeology and Ethnohistory in the Contact Period Caribbean." In Ethnohistory and Archaeology: Approaches to Postcontact Change in the Americas, edited by J. Daniel Rogers and Samuel M. Wilson, 19-30. New York: Plenum Press.

Wing, Elizabeth S. 1961. "Animal Remains Excavated at the Spanish Site of Nueva Cádiz on Cubagua Island, Venezuela." Nieuwe West-Indische Gids 41 (2): 162-165.

Wolf, Eric R. 1982. Europe and the People without History. Berkeley: University of California Press.

Woodward, Robyn P. 2006. "Medieval Legacies: The Industrial Archaeology of an Early Sixteenth-Century Sugar Mill at Sevilla La Nueva, Jamaica." PhD diss., Simon Fraser University.

Wylie, Alison. 1992. "Rethinking the Quincentennial: Consequences for Past and Present." American Antiquity 57 (4): 591-594.

Young, Robert J.C. 1995. Colonial Desire: Hybridity in Theory, Culture, and Race. London: Routledge. 